\title{
EVALUASI PELAKSANAAN PRAKTIK KERJA INDUSTRI SISWA KOMPETENSI KEAHLIAN JASA BOGA SMK N 3 PURWOREJO
}

\author{
Dwi Sapitri Iriani dan Soeharto \\ ${ }^{1}$ SMK N 3 Purworejo, ${ }^{2}$ Universitas Negeri Yogyakarta \\ anggiaharsa@yahoo.co.id; hart_harto@yahoo.co.id
}

\begin{abstract}
This study aims to investigate and evaluate: 1) component of context; 2) component of input; 3) component of process; and 4) component of product. The study employed the CIPP model. The research subjects were 65 respondents. The data were collected through a questionnaire, observations, interviews, and documentation. The quantitative data were processed descriptively using SPSS 16.0 program for Windows. The results of the study showed that for context component, there were $34.9 \%$ students who strongly agreed, $61.5 \%$ who agreed. There were 75\% supervising teachers who strongly agreed, 25\% who agreed. 100\% BS/IS supervisors strongly agreed. The input component, there were 51\% students who strongly agreed, $48.8 \%$ who agreed. There were supervising $87.5 \%$ teachers who strongly agreed, $12.5 \%$ who agreed. $100 \%$ BS/IS supervisors strongly agreed. The process component, there were 30.2\% students who strongly agreed, 48.8\% who agreed. There were $62.5 \%$ supervising teachers who strongly agreed, $37.5 \%$ who agreed. $100 \%$ BS/IS supervisors strongly agreed. The product component, there were $41.9 \%$ students who strongly agreed, 58.1\% who agreed. There were $75.0 \%$ supervising teachers who strongly agreed, $25.0 \%$ who agreed. $100 \%$ BS/IS supervisors strongly agreed. In conclusion, all indicators in each component have been suitable with the implementation of the industrial work practicum in SMK N 3 Purworejo.
\end{abstract}

Keywords: Applied Curriculum, Implementation of the Industrial Work Practicum, CIPP.

\begin{abstract}
ABSTRAK
Penelitian ini bertujuan mengetahui dan mengevaluasi: 1) komponen konteks; 2) komponen input; 3) komponen proses; dan 4) komponen produk. Penelitian ini menggunakan model (CIPP). Subjek penelitian adalah 65 responden. Pengumpulan data dilakukan menggunakan angket, observasi, wawancara, dan dokumentasi. Data kuantitatif diolah secara deskriptif dengan bantuan Program SPSS 16.00 for Windows. Hasil penelitian menunjukkan; komponen konteks, siswa yang sangat setuju 34,9\%, setuju $61,5 \%$. Guru pembimbing yang sangat setuju 75,0\%, setuju 25,0\%. Pembimbing DU/DI (100\%) menyatakan sangat setuju. Komponen input, siswa yang sangat setuju 51,2\%, setuju 48,8\%. Guru pembimbing yang sangat setuju $87,5 \%$, setuju $12,5 \%$. Pembimbing DU/DI (100\%) menyatakan sangat setuju. Komponen proses, siswa yang sangat setuju 30,2\% , setuju 48,8\%. Guru pembimbing yang sangat setuju 62,5\%, setuju 37,5\%. Pembimbing DU/DI (100\%) menyatakan sangat setuju. Komponen produk, siswa yang sangat setuju 41,9\%, setuju 58,1\%. Guru pembimbing yang sangat setuju $75,0 \%$, setuju $25,0 \%$. Semua $(100 \%)$ pembimbing DU/DI menyatakan sangat setuju. Kesimpulannya: semua indikator pada masing-masing komponen telah sesuai dengan pelaksanaan Prakerin di SMK N 3 Purworejo.
\end{abstract}

Kata Kunci: Kurikulum Implementatif, Prakerin, CIPP

\section{PENDAHULUAN}

Era globalisasi membawa dampak yang banyak terhadap kehidupan masyarakat Indonesia. Dampak era globalisasi antara lain adalah adanya bentuk kerjasama dalam dunia usaha dan dampak lainnya adalah adanya persaingan pada dunia kerja yang semakin ketat. Era globalisasi menjanjikan masa depan yang cerah bagi negara yang telah siap menghadapi proses globalisasi dan Indonesia merupakan salah satu negara di dunia yang terkena imbas dari globalisasi tersebut. Untuk menghadapi era globalisasi maka Indonesia memerlukan tenaga kerja yang memiliki keahlian profesional yang tinggi dalam 
menghadapi perkembangan ekonomi global masa kini maupun masa yang akan datang.

Disamping era globalisasi, tantangan lain adalah semakin cepatnya pertambahan penduduk semakin meningkat pula angka pengangguran. Pengangguran terjadi karena tidak seimbangnya antara jumlah tenaga kerja dengan jumlah lapangan kerja yang tersedia. Disisi lain dengan adanya pasar bebas akan semakin meningkatkan persaingan dalam memasuki lapangan kerja. Karena ketatnya persaingan untuk memasuki dunia kerja ini maka sangat dibutuhkan kompetensi yang memadai dan kompetititf sehingga mampu bersaing.

Sekolah Menengah Kejuruan atau SMK merupakan bagian dari Sistem Pendidikan Nasional, yang mempunyai peranan penting dalam menyiapkan dan pengembangan Sumber Daya Manusia. UUSPN No. 20 tahun 2003 pasal 15, menyatakan, pendidikan menengah kejuruan bertujuan untuk menyiapkan peserta didik terutama untuk bekerja dalam bidang tertentu. Tujuan tersebut dapat dijabarkan lagi oleh Depdiknas (2003) menjadi tujuan umum dan tujuan khusus, sebagai berikut. Tujuan umum, sebagai bagian dari sistem pendidikan menengah kejuruan SMK bertujuan: (1) menyiapkan peserta didik agar dapat menjalani kehidupan secara layak, (2) meningkatkan keimanan dan ketakwaan peserta didik, (3) menyiapkan peserta didik agar menjadi warga negara yang mandiri dan bertanggung jawab, (4) menyiapkan peserta didik agar memahami dan menghargai keanekaragaman budaya bangsa Indonesia, dan (5) menyiapkan peserta didik agar menerapkan dan memelihara hidup sehat, memiliki wawasan lingkungan, pengetahuan dan seni. Tujuan khusus, SMK bertujuan: (1) menyiapkan peserta didik agar dapat bekerja, baik secara mandiri atau mengisi lapangan pekerjaan yang ada di dunia usaha dan industri sebagai tenaga kerja tingkat menengah, sesuai dengan bidang dan program keahlian yang diminati, (2) membekali peserta didik agar mampu memilih karir, ulet dan gigih dalam berkompetensi dan mampu mengembangkan sikap profesional dalam bidang keahlian yang diminati, dan (3) membekali peserta didik dengan Ilmu Pengetahuan dan Teknologi (IPTEK) agar mampu mengembangkan diri sendiri melalui jenjang pendidikan yang lebih tinggi.

Menurut Prosser (1949) bahwa pendidikan kejuruan akan lebih efektif jika mampu merubah individu sesuai dengan perhatian, sifat dan tingkat intelegensinya pada tingkat setinggi mungkin, artinya setelah melakukan pendidikan dan pelatihan (diklat) para peserta latihan meningkatkan keterampilannya. Prosser dikenal dengan prinsip-prinsipnya dalam pendidikan vokasional diantaranya adalah: (1) Pendidikan kejuruan akan efisien jika lingkungan dimana siswa dilatih merupakan replika lingkungan dimana nanti ia akan bekerja. (2) Pendidikan kejuruan yang efektif hanya dapat diberikan dimana tugas-tugas latihan dilakukan dengan cara, alat dan mesin yang sama seperti yang ditetapkan di tempat kerja. (3) Pendidikan kejuruan akan efektif jika melatih seseorang dalam kebiasaan berpikir dan bekerja seperti yang diperlukan dalam pekerjaan itu sendiri. (4) Pendidikan kejuruan akan efektif jika pengalaman latihan untuk membentuk kebiasaan kerja dan kebiasaan berpikir yang benar diulang-ulang sehingga sesuai seperti yang diperlukan dalam pekerjaan nantinya. (5) Proses pembinaan kebiasaan yang efektif pada siswa akan tercapai jika pelatihan diberikan pada pekerjaan yang nyata (pengalaman sarat nilai). (6) Sumber yang dapat dipercaya untuk mengetahui isi pelatihan pada suatu okupasi tertentu adalah dari pengalaman para ahli okupasi tersebut.

Sekolah Menengah Kejuruan didirikan untuk menyiapkan kebutuhan tenaga kerja tingkat menengah yang siap kerja dengan bekal keterampilan yang mereka miliki setelah mengikuti pendidikan dan latihan. Lulusan SMK harus memiliki kompetensi sesuai dengan program keahlian yang dipilih dan siap bersaing didunia kerja.

Berdasarkan tujuan pendidikan SMK maka pada program pembelajaran di SMK salah satunya adalah dengan menerapkan program 
sistem ganda. Pendidikan sistem ganda di SMK diterapkan sebagai praktik kerja industri atau disebut prakerin. Prakerin merupakan bagian dari pendidikan sistem ganda (PSG) sebagai program bersama antara SMK dan industri atau institusi pasangan (IP) yang dilaksanakan di dunia usaha, dunia industri. Dalam Kurikulum SMK Depdiknas (2005) disebutkan: Prakerin adalah pola penyelenggaraan pendidikan dan latihan yang dikelola bersama antara SMK dengan industri sebagai institusi pasangan (IP), mulai dari tahap perencanaan, pelaksanaan hingga evaluasi dan sertifikasi yang merupakan satu kesatuan program dengan menggunakan berbagai bentuk alternatif pelaksanaan, seperti day release, block release, dan sebagainya.

Praktek kerja industri (Prakerin) adalah program wajib yang harus diselenggarakan oleh sekolah khususnya SMK dan pendidikan luar sekolah serta wajib diikuti oleh siswa/warga belajar. Kegiatan praktek kerja industri membantu peserta didik untuk menerapkan hasil belajar yang diperoleh di sekolah serta sebagai sarana bagi siswa untuk memperoleh pengalaman nyata bekerja sesuai dengan kondisi di DU/DI.

Dalam skala mikro, pada peserta didik kompetensi keahlian jasa boga SMK Negeri 3 Purworejo diwajibkan mengikuti kegiatan praktik kerja industri pada industri yang menjadi institusi pasangan dengan SMK Negeri 3 Purworejo. Kegiatan praktik kerja industri adalah sebagai sarana siswa untuk latihan bekerja yang memenuhi standar sehingga mereka mampu bersaing secara kompetititf untuk memasuki dunia kerja kelak setelah mereka lulus.

SMK Negeri 3 Purworejo memiliki 4 kompetensi keahlian yaitu : (1) kompetensi keahlian jasa boga; (2) busana butik; (3) kecantikan kulit; dan (4) kecantikan rambut. Pelaksanaan prakerin dilaksanakan selama 3 bulan dan diikuti oleh siswa masing - masing kompetensi keahlian tingkat XII semester 5 . Keputusan untuk melaksanakan prakerin bagi siswa tingkat XII semester 5 karena siswa telah mengikuti pendidikan dan latihan selama 2 tahun dan telah memiliki kompetensi sesuai yang diharapkan oleh DU/DI.

Dari hasil pengamatan awal diketahui bahwa evaluasi program kegiatan praktik kerja industri di SMK Negeri 3 Purworejo belum pernah dilakukan sehingga selama ini belum diketahui permasalahan-permasalahan apa saja yang ada dalam pelaksanaan prakerin. Dari banyaknya permasalahan yang ada dalam pelaksanaan prakerin ada beberapa permasalahan yang perlu untuk dievaluasi.

Kegiatan prakerin SMK Negeri 3 Purworejo diawali dengan persiapan yaitu, pembentukan pokja atau kelompok kerja prakerin yang melibatkan kepala sekolah sebagai penanggungjawab, wakil kepala sekolah bidang hubungan masyarakat dan industri sebagai koordinator prakerin, kepala kompetensi keahlian yang bertugas memetakan siswa untuk DU/DI sesuai kemampuan siswa, dan guru kompetensi keahlian sebagai pembimbing prakerin. Setelah kelompok kerja terbentuk persiapan dilanjutkan dengan menyiapkan berkas administrasi prakerin, penjajagan DU/DI sebagai institusi pasangan dimana siswa akan melaksanakan diklat selama 3 bulan di industri, pemetaan siswa, sosialisasi dengan orangtua siswa dan pembekalan prakerin untuk siswa.

Kegiatan prakerin dimonitor oleh kelompok kerja prakerin melalui guru-guru pembimbing yang dilakukan setiap 1 bulan. Kegiatan monitoring dilakukan untuk mengetahui pelaksanaan prakerin berjalan sesuai dengan harapan sekolah dan DU/DI. Disamping itu agar dapat mengetahui permasalahanpermasalahan apa saja yang terjadi selama pelaksanaan prakerin. Dari hasil monitoring masih ada guru pembimbing yang belum melengkapi pengisian format monitoring dengan lengkap sehingga pokja prakerin belum memperoleh laporan secara lengkap mengenai pelaksanaan prakerin di DU/DI.

Dari hasil pengamatan, permasalahanpermasalahan dalam pelaksanaan prakerin adalah kegiatan pembimbingan yang dilakukan oleh pembimbing DU/DI yang masih bersifat 
sekedarnya. Pembimbing belum bersikap tegas terhadap peserta prakerin karena menganggap peserta sekedar latihan sehingga belum tercipta suasana kerja yang sesungguhnya. Peserta prakerin masih menganggap prakerin sebagai sarana latihan dan belum serius melaksanakan tugasnya.

Di akhir kegiatan prakerin siswa memperoleh sertifikat atau surat keterangan yang menyatakan bahwa siswa telah mengikuti kegiatan prakerin dan telah memiliki pengalaman bekerja di DU/DI dan siap kerja.

Permasalahan dalam kegiatan prakerin ini dievaluasi menggunakan pendekatan CIPP (context, input, process, product). Komponen evaluasi program yaitu: (1) konteks (context) yang ada dalam program praktik kerja industri SMK Negeri 3 Purworejo ditinjau dari kemampuan peserta, pembimbing prakerin, dan faktor kepercayaan DU/DI terhadap kemampuan siswa, (2) masukan (input) yang ada dalam program praktik kerja industri SMK Negeri 3 Purworejo ditinjau dari kesiapan peserta, realisasi penerapan kurikulum implementataif sehingga siswa dapat melaksanakan praktik kerja di DU/DI sesuai dengan kompetensi yang telah diperoleh disekolah. Selain itu pelaksanaan prakerin sesuai dengan visi, misi dan tujuan kompetensi keahlian jasa boga, (3) proses (process) yang ada dalam program praktik kerja industri SMK Negeri 3 Purworejo ditinjau dari pelaksanaan prakerin, keterlibatan siswa peserta prakerin dalam kegiatan kerja di DU/DI dan waktu pelaksanaannya, (4) produk (product) yang ada dalam program praktik kerja industri SMK Negeri 3 Purworejo ditinjau dari pengakuan peningkatan kompetensi siswa oleh pihak DU/DI dengan pemberian sertifikat sebagai bukti siswa telah memiliki pengalaman bekerja di DU/DI dan menyatakan siswa telah siap kerja.

Dari uraian di atas, maka penelitian ini dimaksudkan untuk mengevaluasi program kegiatan prakerin sebagai penyelenggaraan pendidikan yang mengintegrasikan kegiatan pendidikan dan latihan di sekolah dengan kegiatan pendidikan di DU/DI. Dengan kata lain bahwa praktek kerja industri adalah suatu kegiatan dimana siswa mengalami proses belajar melalui bekerja langsung (learning by doing) pada dunia kerja yang sesungguhnya. Dengan praktek kerja industri ini peserta didik memperoleh pengalaman dalam dunia kerja serta membiasakan diri dengan perkembanganperkembangan baru yang selalu muncul didunia industri. Kesesuaian atau proses implementasi materi kompetensi keahlian antara sekolah dengan pihak industri diharapkan dapat sejalan sehingga pihak industri dapat mengetahui bahwa siswa yang melaksanakan kegiatan praktik kerja industri sebenarnya telah menguasai kompetensi yang diberikan di sekolah untuk dapat diterapkan dalam melaksanakan kegiatan praktik kerja industri.

Permasalahan dalam penelitian ini dapat dirumuskan sebagai berikut: (1) Bagaimana kondisi komponen konteks ditinjau dari tujuan program prakerin, kerjasama DU/DI dengan sekolah berdasarkan MoU, harapan agar pelaksanaan prakerin sesuai dengan kurikulum implementatif. (2) Bagaimana kondisi komponen input ditinjau dari pelaksanaan kegiatan Prakerin berkaitan dengan kesiapan peserta, kurikulum implementatif, visi dan misi sekolah serta tujuan kompetensi keahlian jasa boga SMK Negeri 3 Purworejo. (3) Bagaimana kondisi komponen proses ditinjau dari keterlibatan/partisipasi siswa, kerjasama siswa, pemanfaatan waktu dan kemampuan memecahkan masalah pada pelaksanaan kegiatan kerja di industri. (4) Bagaimana kondisi komponen produk ditinjau dari kemampuan penguasaan kompetensi dan sertifikasi siswa setelah pelaksanaan kegiatan Prakerin.

\section{METODE}

Penelitian ini dilakukan untuk mengevaluasi pelaksanaan kegiatan praktik kerja industri siswa kompetensi keahlian jasa boga SMK Negeri 3 Purworejo. Evaluasi merupakan prosedur untuk meneliti keefektifan program dalam mencapai tujuan-tujuannya. 
Pendekatan evaluasi yang digunakan dalam penelitian ini adalah model evaluasi yang dikemukakan Stufflebeam (2002), yang mencakup Context, Input, Process, Product (CIPP). Penelitian ini dilakukan untuk mengetahui sejauh mana pelaksanaan kegiatan praktik kerja industri siswa kompetensi keahlian jasa boga SMK N 3 Purworejo berjalan sesuai harapan sekolah dan industri. Evaluasi dilakukan untuk memperoleh informasi yang akurat mengenai kegiatan Prakerin yang dilakukan dengan membandingkan data hasil penelitian yang diperoleh dengan kriteria yang telah ditentukan sebelumnya, sehingga diperoleh berbagai informasi yang dapat dijadikan sebagai bahan pertimbangan, rekomendasi dan pengambilan kebijaksanaan lebih lanjut guna memperbaiki dan meningkatkan kualitas pelaksanaan kegiatan kompetensi keahlian jasa boga dalam program pelaksanaan Prakerin.

Lokasi penelitian adalah di SMK Negeri 3 Purworejo, Puri Asri Hotel Magelang, RSUD Saras Husada Purworejo dan Pringsewu Restaurant Group Purwokerto. Waktu penelitian dilakukan selama 3 bulan, yaitu pada bulan September sampai dengan bulan Nopember 2013.

Subjek dalam penelitian terdiri dari siswa peserta praktik, penyelenggara atau pokja prakerin SMK Negeri 3 Purworejo. Disamping pihak sekolah, pokja prakerin menggunakan institusi pasangan pengguna jasa tenaga dari siswa peserta praktik yaitu Pringsewu Restaurant Group Purwokerto, Puri Asri Hotel Magelang dan RSUD Saras Husada Purworejo.

Sesuai dengan tujuan penelitian ini adalah untuk mengevaluasi pelaksanaan kegiatan praktik kerja industri siswa kompetensi keahlian jasa boga SMK Negeri 3 Purworejo, maka responden yang digunakan berjumlah 65 org yaitu, 1 orang wakil kepala sekolah bidang humastri sebagai koordinator pokja prakerin SMK Negeri 3 Purworejo, 14 orang pembimbing dari DU/DI, 7 orang pembimbing dari SMK Negeri 3 Purworejo dan 43 siswa peserta prakerin pada DU/DI yang telah ditentukan. Penentuan responden dilakukan berdasarkan lokasi prakerin yaitu Pringsewu Restaurant Group Purwokerto, Puri Asri Hotel Magelang dan RSUD Saras Husada Purworejo.

Teknik pengumpulan data yang digunakan untuk memperoleh data penelitian ini terdiri dari empat macam yaitu angket, observasi, wawancara dan dokumentasi.

(1) Angket merupakan suatu metode yang digunakan untuk menggali data dari semua indikator variabel dalam penelitian dengan memberikan atau menyebarkan daftar pertanyaan atau pernyataan kepada responden dengan harapan memberikan responden data atas daftar pertanyaan tersebut. Pengumpulan data melalui angket dalam hal ini berdasarkan persepsi dari responden itu sendiri tentang jalannya pelaksanaan praktik kerja industri kompetensi keahlian jasa boga SMK N 3 Purworejo.

(2) Observasi adalah suatu pengamatan langsung terhadap suatu kegiatan dengan memperhatikan aktifitas yang ada didalamnya. Dalam observasi peneliti mengamati kegiatan siswa dan pembimbing DU/DI pada saat prakerin. Teknik ini digunakan untuk memperoleh pengalaman atau pengetahuan secara langsung pengenai kegiatan prakerin. Untuk mencatat hasil observasi adalah dengan membuat catatan lapangan (Fieldnotes).

(3) Wawancara adalah pengambilan data dengan cara lisan dalam petemuan tatap muka secara individual (Sukmadinata, 2005:216). Metode wawancara dalam penelitian ini berpedoman pada panduan wawancara (interview guide) yang telah disiapkan sebelumnya yakni tentang pelaksanaan praktik kerja industri siswa kompetensi keahlian jasa boga SMK N 3 Purworejo, adapun yang diwawancarai adalah waka humastri SMK Negeri 3 Purworejo selaku ketua pokja prakerin. (4) Dokumentasi adalah merupakan metode pengumpulan data melalui laporan-laporan, arsip-arsip dan lain-lain (Arikunto,2002:206). Dokumentasi yang digunakan adalah berupa arsip-arsip nilai hasil pelaksanaan kegiatan prakerin SMK Negeri 3 Purworejo. 
Instrumen merupakan alat untuk menjaring data pada kagiatan praktik kerja industri siswa di DU/DI. Instrumen penelitian berupa kuesioner yang bersifat tertutup yaitu menyajikan pertanyaan-pertanyaan yang dibuat dengan alternatif jawaban yang telah disediakan, sehingga responden memilih pilihan jawaban sesuai kondisi yang ada. Skala yang digunakan untuk mengukur instrumen dalam penelitian ini adalah skala Likert dengan empat items jawaban yaitu, skor $4=$ sangat setuju, skor $3=$ setuju, skor $2=$ kurang setuju, $1=$ tidak setuju. Adapun dalam penyusunan instrumen tersebut dibantu dengan kisi - kisi.

Evaluasi atau penilaian berarti tindakan untuk menentukan nilai sesuatu. Dalam arti luas evaluasi adalah suatu proses dalam merencanakan, memperoleh, dan menyediakan informasi yang sangat diperlukan untuk membuat alternatif-alternatif keputusan. Fungsi evaluasi diantaranya adalah sebagai pengukur keberhasilan, dimaksudkan untuk mengetahui sejauh mana suatu program berhasil diterapkan. Dalam penelitian ini, model evaluasi yang digunakan adalah CIPP Evaluation Model (Context Input Process Product).

(1) Evaluasi Konteks, Evaluasi konteks adalah evaluasi terhadap kebutuhan dalam hal ini adalah kebutuhan sekolah untuk meningkatkan kompetensi siswa melalui kegiatan prakerin dengan memperhatikan tujuan program pra-kerin, kerjasama DU/DI dengan sekolah berdasarkan MoU, harapan agar pelaksanaan prakerin sesuai dengan kurikulum implementa-tif. (2) Evaluasi Masukan. Evaluasi masukan mempertimbangkan kemampuan awal yang dimiliki oleh sekolah untuk melaksanakan kegiatan prakerin dalam hal ini adalah siswa peserta prakerin, kurikulum implementatif, visi, misi dan tujuan kompetensi keahlian . (3) Evaluasi Proses. Evaluasi proses diarahkan pada sejauh mana kegiatan prakerin dilaksanakan sesuai dengan kurikulum implementatif dan ketercapaiannya sesuai dengan harapan sekolah dan DU/DI. Kegiatan proses ditinjau mulai dari perencanaan yang meliputi persiapan perangkat, sarana prasarana, penjajagan DU/DI, pendataan siswa, pembekalan, dan sosialisasi. Pelaksanaan prakerin ditinjau dari serah terima siswa pada pihak DU/DI, pembimbingan, monitoring hingga penjemputan. Kegiatan monitoring bertujuan untuk melihat seberapa jauh program prakerin berjalan sesuai dengan harapan, mengetahui kendala-kendala apa saja yang ada selama pelaksanaan prakerin, hingga mencari jalan keluar mengatasi kendala-kendala tersebut. Diakhir pelaksanaan prakerin adalah pemberian nilai dan surat keterangan sebagai bukti siswa telah mengikuti kegiatan prakerin. (4) Evaluasi Hasil. Merupakan tahap akhir evaluasi dimana telah diketahui ketercapaian tujuan prakerin dengan adanya peningkatan kompetensi siswa.

Prakerin merupakan pola penyelenggaraan diklat yang dikelola bersama antara sekolah dengan institusi pasangan yaitu pihak industri. Kegiatan prakerin ini meliputi kegiatan perencanaan, pelaksanaan hingga kegiatan evaluasi dan sertifikasi yang merupakan satu kesatuan program. Prakerin merupakan salah satu kegiatan pembelajaran untuk siswa guna mengasah kemampuan siswa dalam menerapkan kompetensi yang telah diterima selama diklat di sekolah dan harus diterapkan industri dalam kegiatan prakerin. Prakerin dijadikan sarana praktik sebagai perwujudan link and match dari kompetensi yang dipelajari.

Instrumen utama dalam penelitian ini adalah berupa angket. Angket tersebut digunakan untuk mengungkap data dalam pelaksanaan kegiatan praktik kerja industri siswa kompetensi keahlian jasa boga SMK Negeri 3 Purworejo. Untuk menguji apakah angket/ kuesioner dapat digunakan sebagai instrumen maka dilakukan uji validitas dan realibilitas untuk mengetahui angket/kuesioner yang digunakan valid dan reliabel.

Validitas angket sangat ditentukan oleh kejelasan tujuan dan lingkup informasi yang hendak diungkap (Azwar, 2004: 7). Dalam penelitian evaluasi ini, validitas yang digunakan adalah validitas isi. Proses validitas isi dilakukan dengan cara menyusun angket berdasarkan kisi-kisi yang dikembangkan dari 
kajian teoritis yang mendalam dan melalui expert judgement.

Validitas isi juga menunjuk pada sejauh mana isi instrumen merupakan representasi dari ciri-ciri atribut yang hendak diukur. Oleh sebab itu untuk memperoleh tingkat validitas isi yang tinggi suatu tes harus dirancang sedemikian rupa sehingga benar-benar hanya berisi item yang relevan dan perlu menjadi bagian tes secara keseluruhan (Azwar, 2003: 47). Dengan cara ini, diharapkan butir-butir instrumen penelitian ini telah mencakup seluruh kawasan isi objek yang hendak diukur. Untuk menentukan kelayakan butir yang masuk dalam instrumen menggunakan pendapat Sugiyono (2007) bahwa korelasi antara skor item dengan skor total merupakan uji validitas instrumen dan suatu item dianggap valid jika korelasinya diatas 0.30. Analisis validitas butir di dalam penelitian evaluasi ini dilakukan dengan bantuan komputer program Statistical Product and Service Solutions (SPSS) versi 16.0 for Windows, yang selanjutnya disebut dengan program SPSS. Uji coba instrumen dilaksanakan dengan mengambil data dari 43 responden siswa peserta Prakerin dari 65 responden yang digunakan untuk memberikan data.

Validitas isi terhadap angket dalam penelitian evaluasi ini telah ditempuh dengan cara mengembangkan instrumen melalui kisikisi yang disusun berdasarkan kajian teoretis. Kajian teoritis prosesnya dilakukan penelaahan secara cermat oleh penulis dengan pengarahan dosen pembimbing. Setelah mendapatkan persetujuan dosen pembimbing, instrumen penelitian (angket) tersebut diujicobakan di lapangan. Uji coba tersebut juga untuk mengetahui tingkat keterbacaan angket dan validitas butir.

Hasil estimasi validitas butir, dari 55 butir menunjukkan korelasi item-total diatas 0.30 sehingga instrumen dapat diterima, kecuali 1 item pertanyaan pada komponen input dan 3 item pertanyaan pada komponen proses yang dinyatakan gugur. Untuk pedoman observasi ini setelah mendapatkan persetujuan dosen pembimbing langsung digunakan sebagai pedoman dalam melakukan observasi. Rangkuman hasil estimasi validitas angket dapat dilihat pada lampiran 2 .

Setelah proses validasi instrumen, selanjutnya dilakukan analisis untuk mengestimasi reliabilitas instrumen. Tingkat reliabilitas instrumen ditentukan berdasarkan besarnya koefisien reliabilitas yang dimiliki. Semakin tinggi koefisien reliabilitas, semakin tinggi pula reliabilitas instrumen tersebut. Azwar (2003: 188) mengatakan bahwa tidak ada batasan mutlak yang menunjukkan angka koefisien terendah yang harus dicapai agar suatu pengukuran dapat disebut reliabel. Kesepakatan informal menghendaki bahwa koefisien reliabilitas haruslah setinggi mungkin dan koefisien reliabilitas sebesar 0,90 dapat dianggap memuaskan.

Kriteria penetapan batas minimal koefisien reliabilitas yang digunakan dalam penelitian ini adalah mengacu pendapat Kerlinger (2000:662) yaitu koefisien reliabilitas sebesar 0,7 atau lebih dinyatakan handal/ reliabel. Dengan demikian batas minimal koefisien reliabilitas adalah 0,7. Dalam mengestimasi reliabilitas digunakan pendekatan konsistensi internal yaitu dengan melakukan uji coba sekali dan selanjutnya dilakukan penghitungan besarnya reliabilitas. Penghitungan reliabilitas instrumen dilakukan dengan menggunakan formula Alpha dari Cronbach dan dilakukan dengan bantuan komputer program SPSS versi 16.0 for Windows.

Uji coba instrumen dilaksanakan dengan mengambil data dari 43 responden siswa peserta Prakerin SMK Negeri 3 Purworejo. Estimasi reliabilitas dalam pe-nelitian evaluasi ini dilakukan per komponen. Berdasarkan hasil analisis, semua variabel memiliki indeks reliabilitas lebih dari 0,7. Dengan demikian, instrumen ini dapat dapat digunakan untuk mengumpulkan data. Rangkuman hasil estimasi reliabilitas dapat dilihat pada lampiran 3.

Penelitian ini adalah penelitian deskriptif evaluatif yang bertujuan untuk memberikan gambaran hasil suatu program dengan 
menerapkan konsep teori yang dikembangkan terhadap hal-hal yang dievaluasi. Dalam penelitian ini, evaluasi digunakan untuk mengetahui kelancaran jalannya pelaksanaan praktik kerja industri siswa kompetensi keahlian jasa boga SMK Negeri 3 Purworejo. Data hasil obesrvasi, wawancara dan dokumentasi dianalisis secara deskriptif kualitatif. Data kuantitatif diperoleh dari variable konteks, input, proses dan produk dievaluasi. Data dari hasil angket dianalisis secara deskriptif kuantitatif.

Data deskriptif dengan mentabulasikan menurut masing-masing variabel dengan bantuan program SPSS 16,00 for windows akan diperoleh rerata $(\mathrm{M})$, modus $(\mathrm{Mo})$, median $(\mathrm{Me})$ dan standar deviasi (SD). Untuk mengetahui atau mendeskripsikan variabel konteks, input, proses dan produk digunakan skor dengan empat pilihan jawaban yang disediakan.

Data yang diperoleh melalui angket akan dinilai menggunakan kategori tingkat kecenderungan. Tingkat kecenderungan masing -masing variabel dilakukan dengan menetapkan rerata $(\mathrm{M})$, modus (Mo), median $(\mathrm{Me})$ dan standar deviasi (SD), skor tertinggi ideal dan skor terendah ideal dapat dicapai oleh instrumen sebagai kriteria. Adapun pedoman kriteria penilaian dalam penilaian ini dapat dilihat pada Tabel 1.

Tabel 1. Kriteria Evaluasi Pelaksanaan Kegiatan Prakerin

\begin{tabular}{cc}
\hline Interval Nilai & Kriteria \\
\hline $\mathrm{X} \geq \mathrm{Mi}+1,5 \mathrm{Sbi}$ & Sangat Setuju \\
$\mathrm{Mi} \leq \mathrm{X}<\mathrm{Mi}+1,5 \mathrm{Sbi}$ & Setuju \\
$\mathrm{Mi}-1,5 \mathrm{Sbi} \leq \mathrm{X}<\mathrm{Mi}$ & Kurang Setuju \\
$\mathrm{X}<\mathrm{Mi}-1,5 \mathrm{Sbi}$ & Tidak Setuju \\
\hline
\end{tabular}

Keterangan:

$\mathrm{X}$ : Skor responden

Mi : Mean ideal

Sbi : Simpangan baku ideal

Mi : $1 / 2$ (Skor tertinggi ideal + Skor terendah ideal)

SDi : 1/6 (Skor tertinggi ideal - Skor terendah ideal)

Skor tertinggi $=4$

Skor terendah $=1$
$\mathrm{Mi}=1 / 2(4+1)=2,5$

$\mathrm{SDi}=1 / 6(4-1)=0,5$

Skala $4=X \geq 2,5+(1,5 \times 0,5)$

$=\mathrm{X} \geq 3,25$

Skala $3=2,5 \leq X<2,5+(1,5 \times 0,5)$

$=2,5 \leq \mathrm{X}<3,25$

Skala $2=2,5-(1,5 \times 0,5) \leq X<2,5$

$=1,75 \leq \mathrm{X}<2,5$

Skala $1=\mathrm{X}<1,75$

Berdasarkan hasil analisa diatas maka disusun standar skor kategori kecenderungan variabel dan komponen yang dipakai sebagai kriteria dalam evalusai. Analisis statistik deskriptif menggunakan pernyataan sangat setuju, setuju, kurang setuju dan tidak setuju, seperti pada Tabel 2 .

Tabel 2. Standar Skor Kategori Kecenderungan Variabel

\begin{tabular}{cc}
\hline Interval Nilai & Kategori \\
\hline$X \geq 3,25$ & Sangat setuju \\
$2,5 \leq X<3,25$ & Setuju \\
$1,75 \leq X<2,5$ & Kurang setuju \\
$X<1,75$ & Tidak setuju \\
\hline
\end{tabular}

\section{HASIL DAN PEMBAHASAN}

\section{Deskripsi Data Hasil Penelitian}

Berdasarkan data yang telah diperoleh, maka dilakukan analisis terhadap data-data tersebut sehingga dapat menjawab permasalahan-permasalahan yang ada. Adapun rincian hasil olah data adalah sebagai berikut:

\section{Evaluasi Komponen Konteks}

Dalam evaluasi Konteks ini terdiri dari 3 indikator dengan jumlah butir 12 dan 4 pilihan jawaban. Angket dibagikan untuk 43 siswa, 8 guru pembimbing dan 14 pembimbing DU/ DI. Indikator evaluasi konteks dalam penelitian ini meliputi: (1) tujuan program prakerin, (2) kerjasama DU/DI dengan sekolah berdasarkan MoU, (3) harapan agar pelaksana-an prakerin sesuai dengan kurikulum implementatif.

\section{Responden Sis wa}

Berdasarkan hasil analisa data angket untuk siswa diperoleh data dengan nilai rerata/ 
mean sebesar 3,07; median sebesar 3,00; modus sebesar 3,00; dan simpangan baku sebesar 0,36. Distribusi frekuensi dan persentase untuk indikator ini dapat dillihat pada Tabel 3.

Tabel 3. Distribusi Frekuensi dan Persentase Komponen Konteks

\begin{tabular}{cccc}
\hline Kategori & $\begin{array}{c}\text { Rentang } \\
\text { Skor }\end{array}$ & Frekuensi & (\%) \\
\hline Sangat & $\mathrm{X} \geq 3,25$ & 15 & 34,9 \\
setuju & $2,5 \leq \mathrm{X}<$ & 28 & 61,5 \\
Setuju & 3,25 & & \\
Kurang & $1,75 \leq \mathrm{X}$ & - & - \\
setuju & $<2,5$ & & - \\
Tidak & $\mathrm{X}<1,75$ & - & - \\
setuju & Jumlah & 43 siswa & 100 \\
\hline
\end{tabular}

Keterangan : $\mathrm{X}=$ Skor Responden

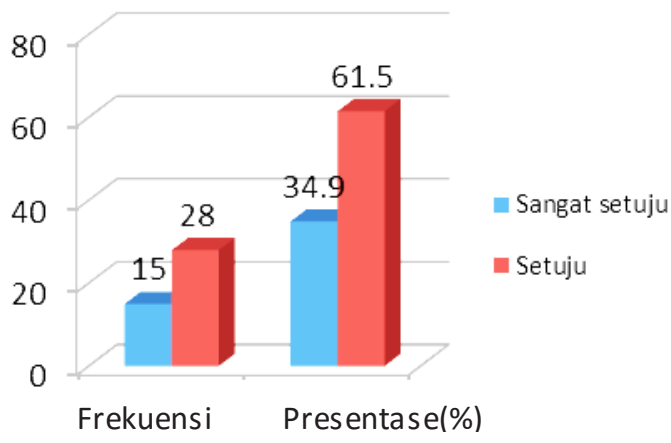

Gambar 1. Diagram Batang Komponen Konteks

Berdasarkan hasil pada Tabel 3 dan Gambar 1 diagram batang diatas, diketahui bahwa pada komponen konteks menurut siswa yang sangat setuju dengan komponen tersebut adalah 15 siswa atau sebesar $34,9 \%$ dan menurut siswa yang setuju berjumlah 28 siswa atau sebesar 61,5\%. Hal ini menunjukkan bahwa komponen konteks dengan indikator indikatornya sangat relevan dengan kegiatan Prakerin

\section{Responden Guru Pe mbimbing}

Pada evaluasi konteks angket dibagikan untuk 8 orang guru pembimbing dengan jumlah butir 12. Evaluasi konteks dalam penelitian ini meliputi (1) tujuan program prakerin; (2) kerjasama DU/DI dengan sekolah berdasarkan
MoU; dan (3) harapan agar pelaksanaan prakerin sesuai dengan kurikulum implementatif.

Berdasarkan hasil analisis data angket untuk guru pembimbing diperoleh nilai rerata/ mean sebesar 3,54; median sebesar 3,59; modus sebesar 3,08; dan simpangan baku sebesar 0,31. Distribusi frekuensi dan persentase untuk komponen konteks dapat dillihat pada Tabel 4.

Tabel 4. Distribusi Frekuensi Dan Persentase Komponen Konteks

\begin{tabular}{cccc}
\hline Kategori & Rentang Skor & Frekuensi & $(\%)$ \\
\hline $\begin{array}{c}\text { Sangat } \\
\text { setuju }\end{array}$ & $\mathrm{X} \geq 3,25$ & 6 & 75,0 \\
$\begin{array}{c}\text { Setuju } \\
\text { Kurang }\end{array}$ & $2,5 \leq \mathrm{X}<3,25$ & 2 & 25,0 \\
setuju & $1,75 \leq \mathrm{X}<2,5$ & - & - \\
$\begin{array}{c}\text { Tidak } \\
\text { setuju }\end{array}$ & $\mathrm{X}<1,75$ & - & - \\
& Jumlah & 8 guru & 100
\end{tabular}

Keterangan : $\mathrm{X}=$ Skor Responden

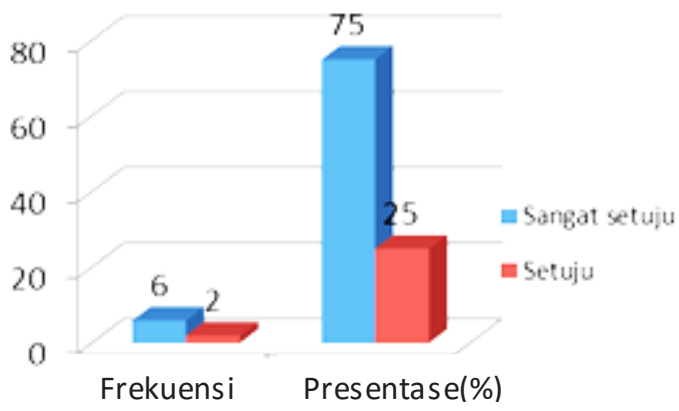

Gambar 2. Diagram Batang Komponen Konteks

Berdasarkan hasil pada Tabel 4 dan Gambar 2 diagram batang Komponen Kontek diatas, diketahui bahwa menurut guru pembimbing yang sangat setuju dengan komponen tersebut adalah 6 orang guru atau sebesar $75,0 \%$ dan menurut guru pembimbing yang setuju berjumlah 2 orang atau sebesar $25,0 \%$. Hal ini menunjukkan bahwa komponen konteks dengan indikator - indikatornya sangat relevan dengan kegiatan Prakerin.

\section{Responden Pembimbing DU/DI}

Pada evaluasi konteks angket dibagikan untuk 14 orang pembimbing dengan jumlah butir 12. Evaluasi konteks dalam penelitian ini 
meliputi (1) tujuan program prakerin; (2) kerjasama DU/DI dengan sekolah berdasarkan MoU; dan (3) harapan agar pelaksanaan prakerin sesuai dengan kurikulum implementatif. Berdasarkan hasil analisis data angket untuk pembimbing diperoleh nilai rerata/ mean sebesar 3,91; median sebesar 3,92; modus sebesar 4,00; dan simpangan baku sebesar 0,10. Distribusi frekuensi dan persentase untuk komponen konteks dapat dillihat pada Tabel 5.

Tabel 5. Distribusi Frekuensi dan Persentase Komponen Konteks

\begin{tabular}{|c|c|c|c|}
\hline Kategori & $\begin{array}{c}\text { Rentang } \\
\text { Skor }\end{array}$ & Frekuensi & $(\%)$ \\
\hline $\begin{array}{l}\text { Sangat } \\
\text { setuju }\end{array}$ & $X \geq 3,25$ & 14 & 100 \\
\hline Setuju & $\begin{array}{c}2,5 \leq X< \\
3,25\end{array}$ & - & - \\
\hline $\begin{array}{l}\text { Kurang } \\
\text { setuju }\end{array}$ & $\begin{array}{c}1,75 \leq X \\
<2,5\end{array}$ & - & - \\
\hline $\begin{array}{l}\text { Tidak } \\
\text { setuju }\end{array}$ & $X<1,75$ & - & - \\
\hline \multicolumn{2}{|c|}{ Jumlah } & 14 & 100 \\
\hline
\end{tabular}

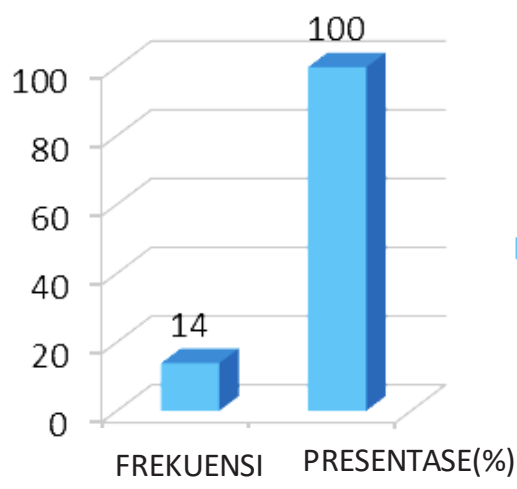

Gambar 3. Diagram Batang Komponen Konteks

Berdasarkan hasil pada tabel dan gambar diagram batang diatas, diketahui bahwa pada komponen konteks, pembimbing yang berjumlah 14 orang seluruhnya atau sebesar $100 \%$ menyatakan sangat setuju dengan komponen tersebut. Hal ini menunjukkan bahwa komponen konteks dengan indikator-indikatornya sangat relevan dengan kegiatan Prakerin.

\section{Evaluasi Komponen Input}

Evaluasi Input dalam penelitian ini meliputi (1) peserta prakerin; (2) kurikulum implementatif; (3) visi dan misi sekolah; dan (4) tujuan kompetensi keahlian. Angket dibagikan untuk 43 siswa , 8 guru pembimbing dan 14 pembimbing DU/DI dengan jumlah butir 15 dan 4 pilihan jawaban.

\section{Responden Siswa}

Berdasarkan hasil analisis data angket untuk siswa diperoleh nilai rerata/mean sebesar 3,30; median sebesar 3,27; modus sebesar 3,07; dan simpangan baku sebesar 0,26. Distribusi frekuensi dan persentase kategori kesesuaian kurikulum dalam pelaksanaan prakerin dapat dilihat pada Tabel 6 .

\section{Tabel 6. Distribusi Frekuensi dan Persentase} Komponen Input

\begin{tabular}{|c|c|c|c|}
\hline Kategori & $\begin{array}{l}\text { Rentang } \\
\text { Skor }\end{array}$ & Frek & $\begin{array}{c}\text { Persentase } \\
(\%)\end{array}$ \\
\hline $\begin{array}{l}\text { Sangat } \\
\text { setuju }\end{array}$ & $X \geq 3,25$ & 22 & 51,2 \\
\hline Setuju & $\begin{array}{c}2,5 \leq X< \\
3,25\end{array}$ & 21 & 48,8 \\
\hline $\begin{array}{c}\text { Kurang } \\
\text { setuju }\end{array}$ & $\begin{array}{c}1,75 \leq X \\
<2,5\end{array}$ & - & - \\
\hline $\begin{array}{l}\text { Tidak } \\
\text { setuju }\end{array}$ & $\mathrm{X}<1,75$ & - & - \\
\hline \multicolumn{2}{|c|}{ Jumlah } & 43 & 100 \\
\hline
\end{tabular}

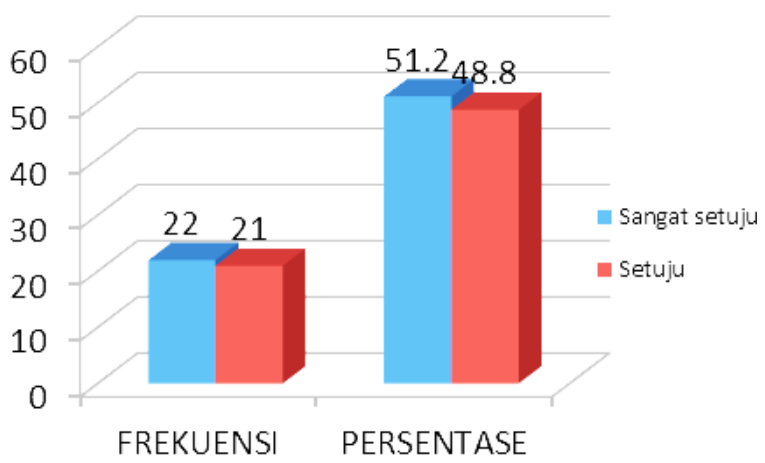

(\%)

\section{Gambar 4. Diagram Batang Komponen Input}

Berdasarkan hasil pada tabel dan gambar diagram batang diatas, diketahui bahwa pada komponen input menurut siswa yang sangat setuju dengan komponen tersebut adalah 22 
siswa atau sebesar $51,2 \%$ dan menurut siswa yang setuju berjumlah 21 siswa atau sebesar 48,8\%. Hal ini menunjukkan bahwa komponen input dengan indikator-indikatornya sangat relevan dengan kegiatan Prakerin.

\section{Responden Guru Pe mbimbing}

Evaluasi input dalam penelitian ini meliputi (1) peserta prakerin; (2) kurikulum implementatif; (3) visi dan misi sekolah; dan (4) tujuan kompetensi keahlian. Angket dibagikan untuk 8 guru pembimbing dengan jumlah butir 15 dan 4 pilihan jawaban. Berdasarkan hasil analisis data angket untuk siswa diperoleh nilai rerata/mean sebesar 3,52; median sebesar 3,50; modus sebesar 3,27; dan simpangan baku sebesar 0,29. Distribusi frekuensi dan persentase kategori kesesuaian kurikulum dalam pelaksanaan prakerinn dapat dilihat pada Tabel 7 .

Tabel 7. Distribusi Frekuensi dan Persentase Komponen Input

\begin{tabular}{cccc}
\hline Kategori & $\begin{array}{c}\text { Rentang } \\
\text { Skor }\end{array}$ & Frekuensi & $\begin{array}{c}\text { Persentase } \\
(\%)\end{array}$ \\
\hline Sangat & $\mathrm{X} \geq$ & 7 & 87,5 \\
setuju & 3,25 & & \\
Setuju & $\begin{array}{c}2,5 \leq \mathrm{X} \\
<3,25\end{array}$ & 1 & 12,5 \\
Kurang & $\begin{array}{c}1,75 \leq \mathrm{X} \\
<2,5\end{array}$ & - & - \\
setuju & $\mathrm{X}<$ & - & - \\
Tidak & $\begin{array}{l}\mathrm{X}< \\
\text { setuju } \\
\text { Jumlah }\end{array}$ & 8 guru & 100 \\
\hline \multicolumn{2}{c}{}
\end{tabular}

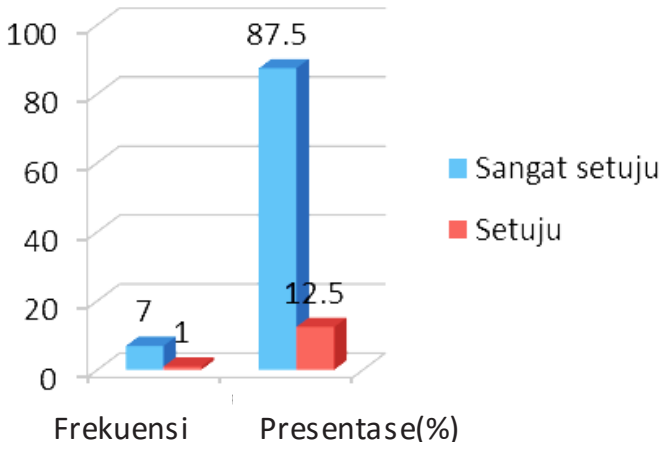

Gambar 5. Diagram Batang Komponen Input
Berdasarkan hasil pada tabel dan gambar diagram batang komponen input diatas, diketahui bahwa menurut guru pembimbing yang sangat setuju dengan komponen tersebut adalah 7 orang guru atau sebesar $87,5 \%$ dan menurut guru pembimbing yang setuju berjumlah 1 orang atau sebesar $12,5 \%$. Hal ini menunjukkan bahwa komponen input dengan indikator - indikatornya sangat relevan dengan kegiatan Prakerin

\section{Responden Pembimbing DU/DI}

Evaluasi input dalam penelitian ini meliputi (1) peserta prakerin; (2) kurikulum implementatif; 3) visi dan misi sekolah; dan (4) tujuan kompetensi keahlian. Angket dibagikan untuk 14 pembimbing dengan jumlah butir 15 dan 4 pilihan jawaban. Berdasarkan hasil analisis data angket untuk pembimbing diperoleh nilai rerata/mean sebesar 3,81; median sebesar 3,80; modus sebesar 3,73; dan simpangan baku sebesar 0,11. Distribusi frekuensi dan persentase kategori kesesuaian kurikulum dalam pelaksanaan prakerin dapat dilihat pada Tabel 8 .

\section{Tabel 8. Distribusi Frekuensi dan Persentase} Komponen Input

\begin{tabular}{cccc}
\hline Kategori & $\begin{array}{c}\text { Rentang } \\
\text { Skor }\end{array}$ & Frekuensi & $(\%)$ \\
\hline Sangat & $\mathrm{X} \geq 3,25$ & 14 & 100 \\
setuju & $2,5 \leq \mathrm{X}<$ & & \\
Setuju & 3,25 & - & - \\
Kurang & $1,75 \leq \mathrm{X}$ & - & - \\
setuju & $<2,5$ & - & - \\
Tidak setuju & $\mathrm{X}<1,75$ & - & 100 \\
\hline \multicolumn{2}{c}{ Jumlah } & 14 &
\end{tabular}

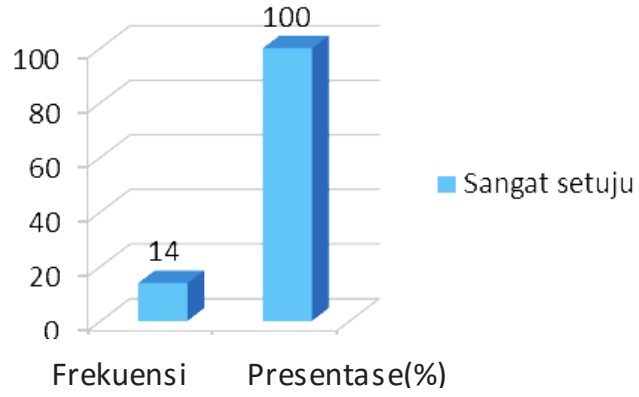

Gambar 6. Diagram Batang Komponen Input 
Berdasarkan hasil pada Tabel 8 dan Gambar 6 diagram batang diatas, diketahui bahwa pada komponen konteks, pembimbing yang berjumlah 14 orang seluruhnya atau sebesar $100 \%$ menyatakan sangat setuju dengan komponen tersebut. Hal ini menunjukkan bahwa komponen konteks dengan indikatorindikatornya sangat relevan dengan kegiatan Prakerin.

\section{Evaluasi Komponen Proses}

Evaluasi proses dalam penelitian ini meliputi (1) keterlibatan/partisipasi siswa pada proses kerja di industri; (2) kerjasama siswa dengan karyawan di DU/DI; (3) pemanfaatan waktu; (4) kemampuan memecahkan masalah; dan (5) pelaksanaan kegiatan. Angket dibagikan untuk 43 siswa, 8 guru pembimbing dan 14 pembimbing DU/DI dengan jumlah butir 18 dan 4 pilihan jawaban.

\section{Responden Siswa}

Berdasarkan hasil analisis data angket untuk siswa diperoleh nilai rerata/mean sebesar 3,05; median sebesar 2,94; modus sebesar 2,88; dan simpangan baku sebesar 0,32. Distribusi frekuensi dan persentase kategori kesesuaian kurikulum dalam pelaksanaan prakerin dapat dilihat pada Tabel 9.

Tabel 9. Distribusi Frekuensi dan Persentase Komponen Proses

\begin{tabular}{cccc}
\hline Kategori & $\begin{array}{c}\text { Rentang } \\
\text { Skor }\end{array}$ & Frekuensi & $(\%)$ \\
\hline $\begin{array}{c}\text { Sangat } \\
\text { setuju }\end{array}$ & $\mathrm{X} \geq 3,25$ & 13 & 30,2 \\
Setuju & $2,5 \leq \mathrm{X}<$ & 30 & 69,8 \\
Kurang & 3,25 & & - \\
$\begin{array}{c}\text { setuju } \\
\text { Tidak }\end{array}$ & $1,75 \leq \mathrm{X}<2,5$ & - & - \\
setuju & $\mathrm{X}<1,75$ & - & - \\
\multicolumn{2}{c}{ Jumlah } & 43 siswa & 100 \\
\hline Keterangan $: \mathrm{X}=$ Skor Responden &
\end{tabular}

Keterangan : X $=$ Skor Responden

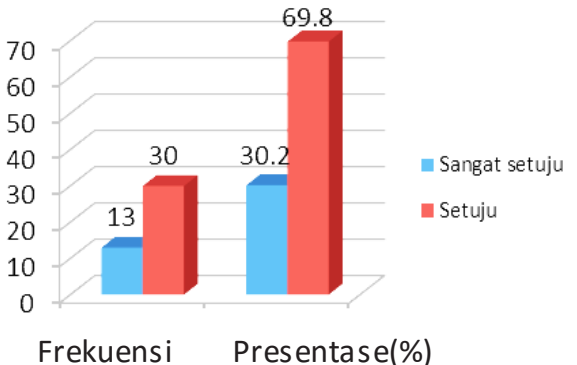

Gambar 7. Diagram Batang Komponen Proses

Berdasarkan hasil pada Tabel 9 dan Gambar 7 diagram batang diatas, diketahui bahwa pada komponen proses menurut siswa yang sangat setuju dengan komponen tersebut adalah 13 siswa atau sebesar 30,2\% dan menurut siswa yang setuju berjumlah 30 siswa atau sebesar 48,8\%. Hal ini menunjukkan bahwa komponen proses dengan indikatorindikatornya sangat relevan dengan kegiatan Prakerin.

\section{Responden Guru pembimbing}

Evaluasi proses dalam penelitian ini meliputi: (1) Keterlibatan/partisipasi siswa pada proses kerja di industri; (2) Kerjasama siswa dengan karyawan di DU/DI; (3) Pemanfaatan waktu; (4) Kemampuan memecahkan masalah; dan (5) Pelaksanaan kegiatan. Angket dibagikan untuk 8 guru pembimbing dengan jumlah butir 20 dan 4 pilihan jawaban. Berdasarkan hasil analisis data angket untuk 8 guru pembimbing diperoleh nilai rerata/mean sebesar 3,39; median sebesar 3,50; modus sebesar 3,53; dan simpangan baku sebesar 0,37. Distribusi frekuensi dan persentase kategori kesesuaian kurikulum dalam pelaksanaan prakerinn dapat dilihat pada Tabel 10.

Tabel 10. Distribusi Frekuensi dan Persentase Komponen Proses

\begin{tabular}{cccc}
\hline Kategori & Rentang Skor & Frekuensi & \\
& & & $(\%)$ \\
\hline Sangat setuju & $\mathrm{X} \geq 3,25$ & 5 & 62,5 \\
Setuju & $2,5 \leq \mathrm{X}<3,25$ & 3 & 37,5 \\
Kurang & $1,75 \leq \mathrm{X}<2,5$ & & \\
setuju & $\mathrm{X}<1,75$ & - & - \\
Tidak setuju & 8 guru & 100 \\
\hline \multicolumn{2}{c}{ Jumlah } & &
\end{tabular}




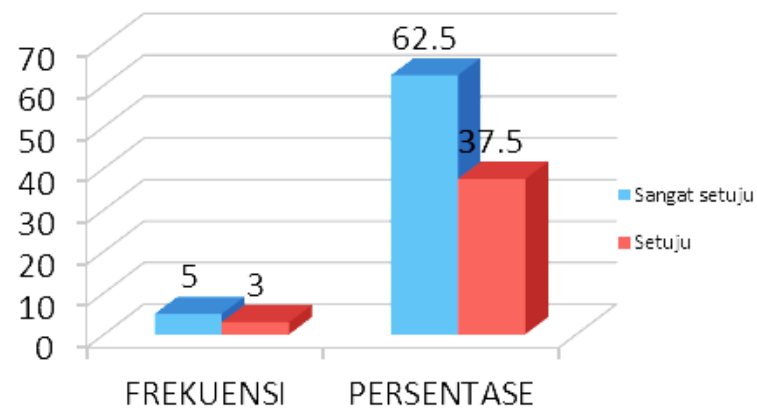

(\%)

Gambar 8. Diagram Batang Komponen Proses

Berdasarkan hasil pada Tabel 10 dan Gambar 8 diagram batang komponen proses diatas, diketahui bahwa menurut guru pembimbing yang sangat setuju dengan komponen tersebut adalah 5 orang guru atau sebesar $62,5 \%$ dan menurut guru pembimbing yang setuju berjumlah 3 orang atau sebesar $37,5 \%$. Hal ini menunjukkan bahwa komponen proses dengan indikator - indikatornya sangat relevan dengan kegiatan Prakerin.

\section{Responden Pembimbing DU/DI}

Evaluasi proses dalam penelitian ini meliputi: (1) Keterlibatan/partisipasi siswa pada proses kerja di industri; (2) kerjasama siswa dengan karyawan di DU/DI (3) pemanfaatan waktu; (4) kemampuan memecahkan masalah; dan (5) pelaksanaan kegiatan. Angket dibagikan untuk 8 guru pembimbing dengan jumlah butir 20 dan 4 pilihan jawaban. Berdasarkan hasil analisis data angket untuk 8 guru pembimbing diperoleh nilai rerata/mean sebesar 3,68; median sebesar 3,74; modus sebesar 3,82; dan simpangan baku sebesar 0,16. Distribusi frekuensi dan persentase kategori kesesuaian kurikulum dalam pelaksanaan prakerinn dapat dilihat pada Tabel 11.

Tabel 11. Distribusi Frekuensi dan Persentase Komponen Proses

\begin{tabular}{cccc}
\hline Kategori & Rentang Skor & Frekuensi & $(\%)$ \\
\hline Sangat setuju & $\mathrm{X} \geq 3,25$ & 14 & 100 \\
Setuju & $2,5 \leq \mathrm{X}<3,25$ & - & - \\
Kurang setuju & $1,75 \leq \mathrm{X}<2,5$ & - & - \\
Tidak setuju & $\mathrm{X}<1,75$ & - & - \\
Jumlah & 14 & 100 \\
\hline Keterangan $: \mathrm{X}=$ Skor Responden &
\end{tabular}




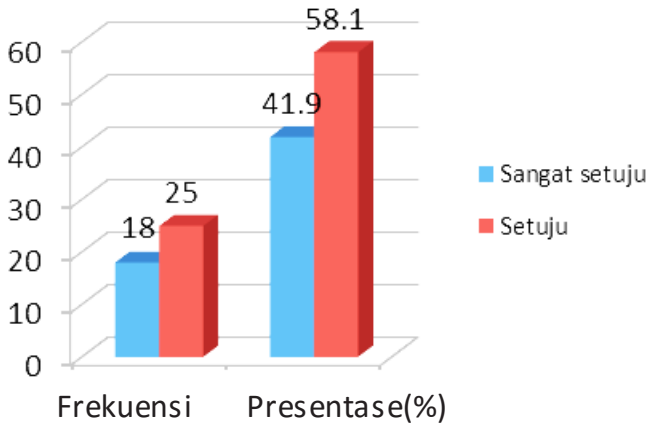

Gambar 10. Diagram Batang Komponen Produk

Berdasarkan hasil pada Tabel 12 dan Gambar 10 diagram batang diatas, diketahui bahwa pada komponen produk menurut siswa yang sangat setuju dengan komponen tersebut adalah 18 siswa atau sebesar $41,9 \%$ dan menurut siswa yang setuju berjumlah 25 siswa atau sebesar 58,1\%. Hal ini menunjukkan bahwa komponen produk dengan indikator indikatornya sangat relevan dengan kegiatan Prakerin.

\section{Responden Guru Pe mbimbing}

Evaluasi produk dalam penelitian ini meliputi: (1) kemampuan kompetensi siswa dan (2) sertifikasi siswa. Angket dibagikan untuk 8 guru pembimbing dengan jumlah butir 7 dan 4 pilihan jawaban. Berdasarkan hasil analisis data angket untuk 8 guru pembimbing tersebut diperoleh nilai rerata/mean sebesar 3,55; median sebesar 3,64; modus sebesar 3,71; dan simpangan baku sebesar 0,35. Distribusi frekuensi dan persentase kategori kesesuaian kurikulum dalam pelaksanaan prakerin dapat dilihat pada Tabel 13.

Tabel 13. Distribusi Frekuensi dan Persentase Komponen Produk

\begin{tabular}{cccc}
\hline Kategori & $\begin{array}{c}\text { Rentang } \\
\text { Skor }\end{array}$ & Frekuensi & $(\%)$ \\
\hline $\begin{array}{c}\text { Sangat } \\
\text { setuju }\end{array}$ & $\mathrm{X} \geq 3,25$ & 6 & 75,0 \\
Setuju & $2,5 \leq \mathrm{X}<3,25$ & 2 & 25,0 \\
Kurang & $1,75 \leq \mathrm{X}<2,5$ & - & - \\
setuju & & & \\
Tidak & $\mathrm{X}<1,75$ & - & - \\
setuju & Jumlah & 8 guru & 100 \\
Keterangan : $\mathrm{X}=$ Skor Responden & &
\end{tabular}

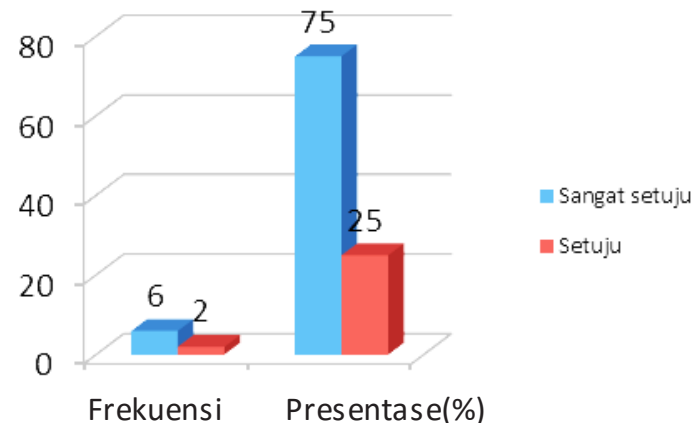

Gambar 11. Diagram Batang Komponen Produk

Berdasarkan hasil pada Tabel 13 dan Gambar 11 diagram batang diatas, diketahui bahwa pada komponen produk menurut guru pembimbing yang sangat setuju dengan komponen tersebut adalah 6 orang guru atau sebesar $75,0 \%$ dan guru pembimbing yang setuju berjumlah 2 orang atau sebesar $25,0 \%$. Hal ini menunjukkan bahwa komponen produk dengan indikator - indikatornya sangat relevan dengan kegiatan Prakerin.

\section{Responden Pembimbing DU/DI}

Evaluasi produk dalam penelitian ini meliputi: (1) kemampuan kompetensi siswa dan (2) sertifikasi siswa. Angket dibagikan untuk 14 pembimbing dengan jumlah butir 7 dan 4 pilihan jawaban. Berdasarkan hasil analisis data angket untuk 14 pembimbing tersebut diperoleh nilai rerata/mean sebesar 3,75; median sebesar 3,71; modus sebesar 3,71; dan simpangan baku sebesar 0,17 . Distribusi frekuensi dan per-sentase kategori kesesuaian kurikulum dalam pelaksanaan prakerinn dapat dilihat pada tabel 55 .

Tabel 14. Distribusi Frekuensi dan Persentase Komponen Produk

\begin{tabular}{|c|c|c|c|}
\hline Kategori & $\begin{array}{c}\text { Rentang } \\
\text { Skor }\end{array}$ & Frekuensi & $\begin{array}{c}\text { Persentase } \\
(\%)\end{array}$ \\
\hline $\begin{array}{l}\text { Sangat } \\
\text { setuju }\end{array}$ & $\begin{array}{l}X \geq \\
3,25\end{array}$ & 14 & 100 \\
\hline Setuju & $\begin{array}{c}2,5 \leq X \\
<3,25\end{array}$ & - & - \\
\hline $\begin{array}{c}\text { Kurang } \\
\text { setuju }\end{array}$ & $\begin{array}{c}1,75 \leq X \\
<2,5\end{array}$ & - & - \\
\hline $\begin{array}{l}\text { Tidak } \\
\text { setuju }\end{array}$ & $X<1,75$ & - & - \\
\hline \multicolumn{2}{|c|}{ Jumlah } & 14 & 100 \\
\hline
\end{tabular}




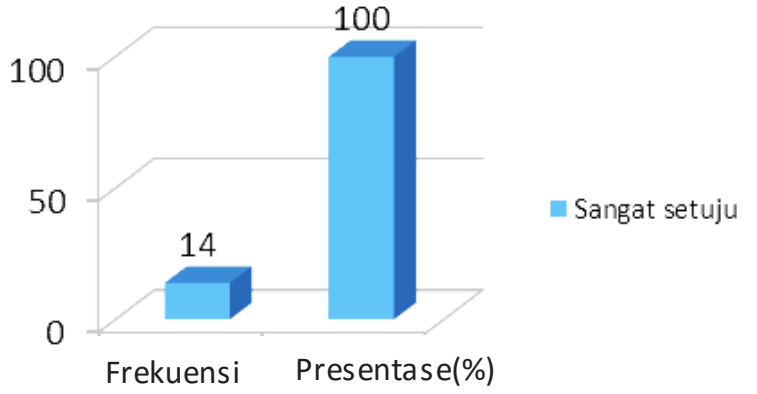

Gambar 12. Diagram Batang Komponen Produk

Berdasarkan hasil pada Tabel 14 dan Gambar 12 diagram batang diatas, diketahui bahwa pada komponen konteks, pembimbing yang berjumlah 14 orang seluruhnya atau sebesar $100 \%$ menyatakan sangat setuju dengan komponen tersebut. Hal ini menunjukkan bahwa komponen konteks dengan indikator indikatornya sangat relevan dengan kegiatan Prakerin.

\section{SIMPULAN}

Berdasarkan hasil penelitian yang dilakukan tentang evaluasi pelaksanaan praktik kerja industri siswa kompetensi keahlian jasa boga SMK Negeri 3 Purworejo, dapat ditarik kesimpulan sebagai berikut: (1) Secara keseluruhan pelaksanaan Prakerin dalam komponen konteks yang ditinjau dari: 1) tujuan program Prakerin, 2) kerjasama DU/DI dengan sekolah berdasarkan MoU, 3) harapan agar pelaksanaan Prakerin sesuai dengan kurikulum implementatif, data yang diperoleh dari hasil angket, observasi, wawancara semuanya telah dilaksanakan dan sesuai dengan tujuan program Prakerin SMK Negeri 3 Purworejo. (2) Secara keseluruhan pelaksanaan Prakerin dalam komponen input yang diperoleh dari hasil observasi, wawancara semuanya telah dilaksanakan dan sesuai dengan program Prakerin, dan hasil yang diperoleh dari angket input ditinjau dari: 1) peserta Prakerin, 2) kurikulum implementatif, 3) visi dan misi sekolah, dan 4) tujuan kompetensi keahlian, telah sesuai dengan program kegiatan Prakerin SMK Negeri 3 Purworejo. (3) Secara keseluruhan pelaksanaan Prakerin dalam komponen proses yang diperoleh dari hasil observasi, wawancara semuanya telah dilaksanakan dan sesuai dengan program Prakerin, dan hasil yang diperoleh dari angket ditinjau dari: 1) keterlibatan/partisipasi siswa pada proses kerja di industri, 2) kerjasama siswa dengan karyawan di DU/DI, 3) pemanfaatan waktu, 4) kemampuan memecahkan masalah, dan 4) pelaksanaan kegiatan, telah sesuai dengan program kegiatan Prakerin SMK Negeri 3 Purworejo. (4) Secara keseluruhan pelaksanaan Prakerin dalam komponen produk yang diperoleh dari hasil observasi, wawancara semuanya telah dilaksanakan dan sesuai dengan program Prakerin, dan hasil yang diperoleh dari angket ditinjau dari: 1) kemampuan kompetensi siswa dan 2) sertifikasi siswa, telah sesuai dengan program kegiatan Prakerin SMK Negeri 3 Purworejo. (5) Sekolah dalam hal ini pokja Prakerin telah melaksanakan tugasnya dengan baik melalui berbagai tahapan kegiatan dimulai dari persiapan, pembekalan, proses pelaksanaan, monitoring evalusai hingga penarikan kembali siswa oleh pihak sekolah. Secara keseluruhan pelaksanaan Prakerin telah berlangsung dengan baik. (6) Kurikulum implementatif sebagai kurikulum sinkronisasi yang disusun oleh pihak DU/DI dan pihak sekolah benar - benar telah sesuai dan diterapkan pada kegiatan Prakerin siswa sehingga pelaksanaan Prakerin berjalan lancar, efisien dan efektif. (7) Selalu ada komunikasi yang baik antara pihak sekolah dengan pihak DU/DI sehingga kerja sama selalu terjalin. Hal ini sangat membantu guna pelaksanaan Prakerin-Prakerin selanjutnya. Dan selalu diusahakan pada pelaksanan Prakerin tidak ada permasalahan antara siswa, DU/DI dan sekolah sehingga pelaksanaan Prakerin selalu memberikan kesan yang baik. (8) Kegiatan Prakerin adalah kegiatan yang sangat bermanfaat bagi siswa karena memberikan bekal dalam membentuk sikap mental siswa untuk siap terjun kedunia kerja setelah mereka lulus. Kegiatan Prakerin juga berfungsi sebagai sarana untuk mengetahui 
apakah potensi yang ada pada diri siswa telah sesuai dengan harapan dunia industri.

Berdasarkan kesimpulan hasil penelitian, diharapkan program praktik kerja industri ini dilanjutkan secara berkesinambungan dengan lebih mengembangkan program-program yang telah dilaksanakan agar menjadi lebih baik lagi, untuk itu disarankan agar: (1) Penjajagan industri sebagai institusi pasangan SMK Negeri 3 Purworejo lebih ditingkatkan dengan memilih DU/DI yang dapat menampung siswa dan dapat memberikan pengalaman kerja yang lebih bermanfaat bagi siswa. (2) Mengevaluasi waktu pelaksanaan, apakah perlu dilaksanakan Prakerin dengan waktu pelaksanaan lebih dari 3 bulan ataukah tetap cukup dengan waktu pelaksaan 3 bulan (3) Tetap menjalin kerjasama dengan DU/DI diluar jalur Prakerin misalnya pada jalur perekrutan tenaga kerja, kegiatan table manner jika DU/DI yang digunakan adalah hotel, agar tetap terjalin hubungan kerjasama sehingga kegiatan Prakerin tetap berjalan lancar dan pihak sekolah tidak kesulitan mencari tempat prakrik untuk siswa. (4) Memberikan pengertian pada siswa bahwa kegiatan Prakerin adalah sarana untuk latihan bekerja, sehingga jangan pernah berharap mendapatkan materi berupa uang karena sesungguhnya pengalaman yang diperoleh siswa jauh lebih berharga daripada uang. (5) Selalu mengingatkan siswa untuk mengerjakan tugas modul sebagai sarana belajar jarak jauh, karena masih ada siswa peserta Prakerin yang tidak mengerjakan modul dan baru mengumpulkan tugas modul setelah kegiatan Prakerin berakhir. (6) Mengingatkan siswa untuk mengisi jurnal dibawah pengawasan pembimbing agar nilai Prakerin dapat segera direkap oleh guru pembimbing. (7) Mengingatkan guru pembimbing untuk mengisi format monitoring dengan lengkap agar mempermudah komunikasi antar sekolah dengan DU/DI.

\section{DAFTAR RUJUKAN}

Arikunto, S. 2006. Prosedur Penelitian (suatu pendekatan praktik). Jakarta: Rineksa Cipta

Depdiknas. 2003. Undang - Undang RI Nomor 20, Tahun 2003, Tentang Sistem Pendidikan Nasional

Depdiknas. 2005. Panduan praktik kerja industri, Jakarta: Dikmenjur

Depdiknas. 2005. Pendidikan sistem ganda, Jakarta: Dikmenjur

Issac, S \& Michael, W.B. 1984. Handbook in research and evaluation. California: Edits Publishing

Kerlinger F.N dan Lee H.B. 2000. Foundation of behavioural research, $\left(4^{\text {rd }} e d\right)$. California: Harcounut College Publishers

Program Pasca Sarjana. 2011 Pedoman tesis dan disertasi. Universitas Negeri Yogyakarta

Prosser, CA. 1949. Prinsip pendidikan vokasional, diambil pada hari selasa tanggal 11 maret 2014 dari http://1ptk.blogspot.com/2011/11/prinsip -pendidikan-vokasional-dari.html

Saifuddin Azwar. 2003. Reliabilitas dan validitas. Yogyakarta: Pustaka Pelajar

Stufflebeam D. L. \& Skinfield A. J. 1984. Sistematic evaluation. United States of Amerika: Kluwer Nijhoff Publhising

Stufflebeam, DL. 2002. CIPP:a mode for program evaluation. Diambil pada tanggal 9 Oktober 2012 dari http://GG.218.71.225/search/cache 
2006. Peraturan Menteri Pendidikan Nasional Republik Indonesia Nomor 22, Tahun 2006, tentang Standar Isi

1990. peraturan pemerintah nomor 29 tentang Pendidikan Menengah

Sugiyono. 2007. Metode Penelitian Kualitatif dan $R \& D$. Bandung: Alfabeta 